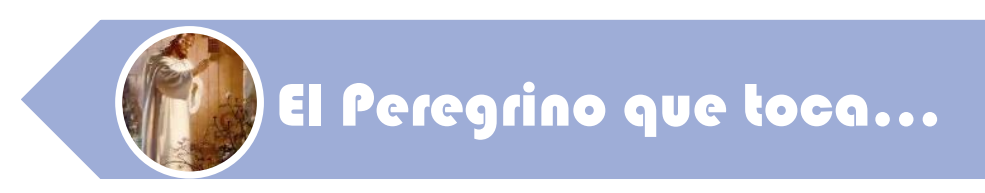

\title{
¿COMO CONUIUES EN TU COMUNIDAD CORPISTA?
}

Gabriel Sáenz ${ }^{\ddagger \neq \neq}$

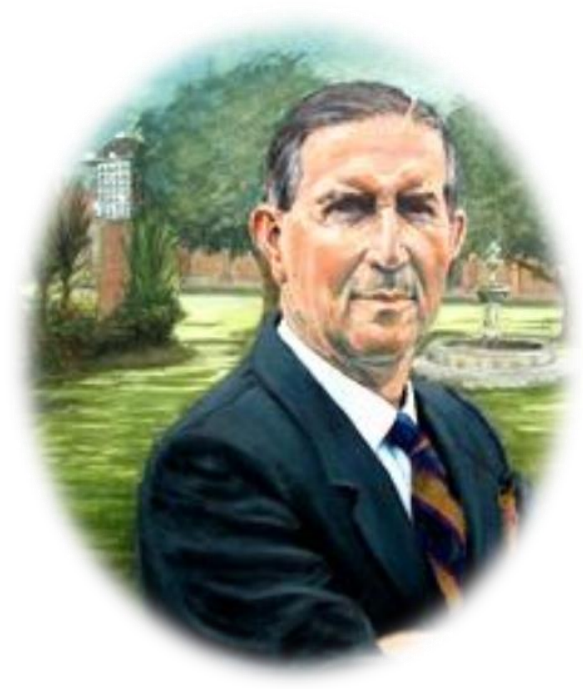

Esta vez el peregrino toca a la puerta de la convivencia corpista y nos pregunta: ¿Cómo convives dentro de esta comunidad?

Tienes todo el derecho de avanzar, sobresalir, colaborar y luchar por ser el mejor, pero ¿a qué precio?

La pregunta del peregrino nos cuestiona sobre algo que a muchos les puede sonar como un tema religioso, ime refiero a las virtudes!

Realmente el término virtud (del latín virtus) nace dentro de un ambiente pagano, es decir antes de la era cristiana. Muchos filósofos griegos, como Aristóteles, Platón y Sócrates se refieren a las virtudes. Luego, con el cristianismo, las virtudes se cristianizaron, ya que Jesús fue un hombre virtuoso. San Agustín se refiere a ellas en el Kempis Agustiniano. "Nos hiciste para ti Señor" (1).

En forma sencilla, las virtudes son hábitos moralmente buenos, contrario a los hábitos malos llamados vicios. Existe un grupo de virtudes principales (cardinales), pues de estas se desprenden todas las demás y son:
La prudencia.
v La justicia.
v La fortaleza.
La templanza.

Para referirme a la convivencia, se debe hablar de la virtud de la templanza, es decir: "la moderación en los bienes naturales, en la búsqueda de honores y éxitos, y en la templanza de la ira", en otras palabras, luchar contra la arrogancia, la vanagloria, la petulancia, la omnipotencia, la ostentación, el abuso del poder y los arrebatos de ira.

Si no dominamos estos instintos, nuestra comunidad se verá afectada en una convivencia difícil, agria y ácida, contrario a las directrices y normas de caballerosidad y decencia de nuestro fundador, el Doctor Jorge Piñeros Corpas.

A este respecto, el Peregrino nos propone el mensaje de San Pablo a la comunidad de los efesios:

${ }^{\ddagger \neq \neq \neq}$ Capellán CJNC. Consejero Estudiantil FUJNC. 
"Eliminen la mentira y diganse la verdad unos a otros... E $\mathcal{E}$ que robaba no robe más y póngase a trabajar honestamente con sus manos para ganar algo y poder socorrer al que tiene necesidad. No salga de sus bocas ninguna palabra ofensiva, sino las palabras buenas que ayuden a crecer a quien to necesita y agraden a quien los escucha... Eviten toda amargura, pasión, odio, gritos, insultos y cualquier tipo de maldad. Sean amables y compasivos unos con otros. Perdónense unos a otros como Dios los ha perdonado en Cristo" (Efesios 4: 29-32).

Querida comunidad corpista, San José es nuestro patrono de la Sala de Paz de la Clínica, pues es el abogado de la buena muerte, hombre virtuoso, nos enseña a comportarnos en nuestra comunidad a través de la siguiente oración:

Bienaventurado San José:

Enséñanos a no hacer protagonismos, a avanzar sin pisotear a nadie, a colaborar sin imponernos,

a amar sin reclamar

a ser humildes como tú.

Dinos San José

cómo se vive siendo "número dos"

y cómo se hacen cosas extraordinarias desde un "segundo puesto".

Explícanos San José cómo ser grandes sin exhibirnos, cómo luchar sin aplausos, cómo perseverar y morir sin esperar homenajes. AMÉN.

\section{PROPUESTAS:}

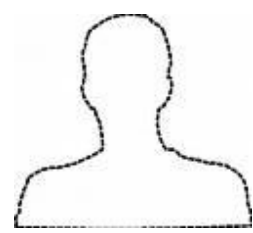

Reflexiona sobre el siguiente pensamiento de San Agustín (2):

"Vale más una piadosa ignorancia que una ciencia presuntuosa".

"Es más apreciable una sencilla confesión de carencia de ciencia que la jactancia temeraria de mucho saber."

\section{Referencias:}

(1) San Agustín. Nos hiciste, Señor, para ti. Kempis agustiniano. Madrid: BAC, 206. 675 p, ISBN. 10:84 - 7914-043-7.

(2) Ibídem p. 520.
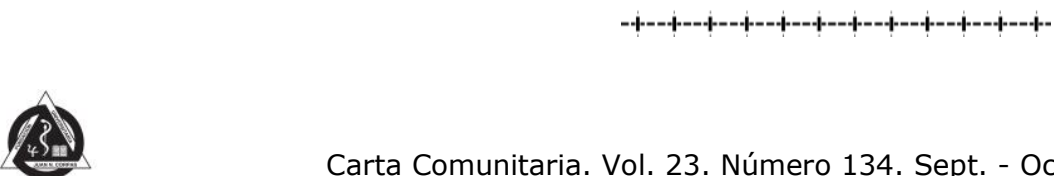

Carta Comunitaria. Vol. 23. Número 134. Sept. - Oct. 2015 